\title{
Ultrasensitive bioassaying of HER-2 protein for diagnosis of breast cancer using reduced graphene oxide/chitosan as nanobiocompatible platform
}

Hassan Nasrollahpour ${ }^{1}$, Ibrahim Isildak², Mohammad-Reza Rashidi ${ }^{3}$, Esmat Alsadat Hashemi ${ }^{4}$, Abdolhosein Naseri ${ }^{*^{*}}$ and Balal Khalilzadeh ${ }^{*^{*}}$ (D)

*Correspondence:

a_naseri@tabrizu.ac.ir;

khalilzadehb@tbzmed.ac.ir;

balalkhalilzadeh@gmail.com

${ }^{1}$ Department

of Analytical Chemistry,

Faculty of Chemistry,

University of Tabriz, PO

Box 51644-14766, Tabriz, Iran

${ }^{5}$ Stem Cell Research Center,

Tabriz University of Medical

Sciences, 51664-14766 Tabriz, Iran

Full list of author information is available at the end of the article

\begin{abstract}
Background: In this label-free bioassay, an electrochemiluminescence (ECL) immunosensor was developed for the quantification of breast cancer using HER-2 protein as a metastatic biomarker.

Method: For this purpose, the ECL emitter, $\left[\mathrm{Ru}(\mathrm{bpy})_{3}\right]^{2+}$, was embedded into biocompatible chitosan (CS) polymer. The prepared bio-composite offered high ECL reading due to the depletion of human epidermal growth factor receptor 2 (HER-2) protein. Reduced graphene oxide ( $\mathrm{r} G \mathrm{O}$ ) was used as substrate to increase signal stability and achieve greater sensitivity. For this, rGO was initially placed electrochemically on the glassy carbon electrode (GCE) surface by cyclic voltammetry (CV) technique. Next, the prepared CS/[Ru(bpy) $\left.)_{3}\right]^{2+}$ biopolymer solution was coated on a drop of the modified electrode such that the amine groups of CS and the carboxylic groups of $\mathrm{rGO}$ could covalently interact. Using EDC/NHS chemistry, monoclonal antibodies (Abs) of HER-2 were linked to $\mathrm{CS} /\left[\mathrm{Ru}(\mathrm{bpy})_{3}\right]^{2+} / \mathrm{rGO} / \mathrm{GCE}$ via amide bonds between the carboxylic groups of Ab molecules and amine groups of CS. The electrochemical behavior of the electrode was studied using different electrochemical techniques such as electrochemical impedance spectroscopy (EIS), differential pulse voltammetry (DPV) and square wave voltammetry (SWV) and also ECL tests.
\end{abstract}

Results: After passing all optimization steps, the lower limit of detection (LLOQ) and linear dynamic range (LDR) of HER-2 protein were practically obtained as $1 \mathrm{fM}$ and $1 \mathrm{fM}$ to $1 \mathrm{nM}$, individually. Importantly, the within and between laboratory precisions were performed and the suitable relative standard deviations (RSDs) were recorded as 3.1 and $3.5 \%$, respectively.

Conclusions: As a proof of concept, the designed immunosensor was desirably applied for the quantification of HER-2 protein in breast cancer suffering patients. As a result, the designed ECL-based immunosensor has the capability of being used as source, provide a link to the Creative Commons licence, and indicate if changes were made. The images or other third party material in this article are included in the article's Creative Commons licence, unless indicated otherwise in a credit line to the material. If material is not included in the article's Creative Commons licence and your intended use is not permitted by statutory regulation or exceeds the permitted use, you will need to obtain permission directly from the copyright holder. To view a copy of this licence, visit http://creativecommons.org/ licenses/by/4.0/. The Creative Commons Public Domain Dedication waiver (http://creativecommons.org/publicdomain/zero/1.0/) applies to the data made available in this article, unless otherwise stated in a credit line to the data. 
a conventional test method in biomedical laboratories for early detection of HER-2 protein in biological fluids.

Keyword: HER-2, ECL, Bioassay, Breast cancer, Biomedical analysis, Ruthenium, Protein, Biocompatible polymer, Chitosan, Biotechnology, $\left[\mathrm{Ru}(\mathrm{bpy})_{3}\right]^{2+}$

\section{Background}

Breast cancer $(\mathrm{BC})$ is the most prevalent carcinoma among in the world of women at the moment. Despite many advances that have been reported for the therapy, but it still sounds as the first order death reason in females (Tang et al. 2019; Cao et al. 2016). Global concerns of BC spreading, high prices for curing and diagnostic drawbacks triggering the demands for costly effective, rapid and on-site recognition of this disease (Min et al. 2018; Huang et al. 2019; Zamani-Ahmadmahmudi et al. 2014). Considering some drawbacks of traditional therapeutic (cytology or histopathology) and theranostic procedures such as high costs, ineffective cures and late recognition, processes appeal new effective detection protocols that can address the issues. Among many advancements in bioanalytical domain, emerging biosensors regarded as a milestone for future hopes. These devices have been trusted by many diagnostic domains for recognition of diseases. Electrochemiluminescence (ECL) protocols are one of the best for clinical diagnosis which enable accurate determinations with desirable selectivity and sensitivity (Reta et al. 2018; Oliveira et al. 2018; Zhu et al. 2012; Kilic et al. 2012). Owing to its supreme efficiency features, including low-background emission and superfine sensitivity, ECL methodologies have realized extensive diagnostic application for various analytes (Lv et al. 2018; Kitte et al. 2017; Truong et al. 2019; Nasrollahpour et al. 2021; Khalilzadeh et al. 2017). Among ECL systems, inorganic systems (such as $\left[\mathrm{Ru}(\mathrm{bpy})_{3}\right]^{2+}$ are the one of the most well known for their high ECL yield (Dong et al. 2016; Fang et al. 2020; Kalaiyarasan et al. 2020). $\left[\mathrm{Ru}(\mathrm{bpy})_{3}\right]^{2+}$ has attracted great success for in vitro recognition purposes. This is due to its superb sensitivity, easy to use and broad dynamic range. Coreactant-assisted ECLs of ruthenium complexes (including $\left[\mathrm{Ru}(\mathrm{bpy})_{3}\right]^{2+}$ ) play substantial act in analytical and bioanalytical applications. Coreactant-assisted ECLs mainly consist of two types: I) oxidativereductive ECL emissions and II) reductive-oxidative ECL emissions. $\left[\mathrm{Ru}(\mathrm{bpy})_{3}\right]^{2+}$ system is an oxidative-reductive system, in which, a positive potential range is adapted which limited the oxygen evolution effect on ECL intensity in aqueous solutions. Coreactants play an important role in ECL quantum yields. Tri-propyl amine (TPrA) is a well-known coreactant of $\left[\mathrm{Ru}(\mathrm{bPy})_{3}\right]^{2+}$ which is widely employed in laboratorial and commercial assays (Richter 2004; Liu et al. 2015; Li et al. 2017; Zanut et al. 2020).

Nanoconstructed materials introduced in the recent years as attractive materials in various fields including biosensing investigations (Li et al. 2010; Sanvicens et al. 2009; Luo et al. 2006; Nakhjavani et al. 2019). Graphene oxide (GO), conductive polymers and also their derivatives are commonly used in biomedical applications (ZamaniAhmadmahmudi et al. 2014; Nakhjavani et al. 2019; Hatamzadeh and Jaymand 2014; Massoumi et al. 2015). Excellence in physicochemical characteristics such as high 
surface-to-volume ratio and desirable conductivity, have made nanomaterials as excellent candidates for modification of biosensing transducers including electrochemical and ECL frameworks (Babaei et al. 2010; Karim-Nezhad et al. 2009; Khalilzadeh et al. 2011; Saghatforoush et al. 2009). Various types of nanomaterials with different shapes and sizes are considerably applied in ECL biosensing of BC such as gold nanoparticles (AuNPs) (Zhu et al. 2012), silver nanoparticles (AgNPs) (Yazdanparast et al. 2018), silver nanoclusters (AgNCs) (Guo et al. 2015), ZnO nanowires (ZnNWs) (Mansor et al. 2014), and CNTs (Nawaz et al. 2016). One of the drawbacks of the mentioned nanostructures is their expensiveness and poor functionality in some cases. Among different nanomaterials, graphene-based nanosheets attracted great interests considering their good conductivity, high loading capacity, good functionality and desirable stability. Also, graphene can simply produce in inexpensive way (Li et al. 2013).

There are several reports based on graphene modified electrodes for electrochemiluminescence determinations using tris(2,2-bipyridyl) ruthenium (II) $\left[\mathrm{Ru}(\mathrm{bpy})_{3}\right]^{2+}$ ) as ECL indicator. For instance, Li et al. developed an electrochemiluminescence biosensing strategy advantaging a triple combination of graphene-nafion- $\left[\mathrm{Ru}(\mathrm{bpy})_{3}\right]^{2+}$. Another ECL method was introduced by Wang and coworkers using graphene modified electrode. In this probe graphene nanosheets (GNSs) were exploited as desirable supporting substrate to hold ECL indicator. CS was employed as adhesive compound for this purpose (Wang et al. 2012). Employing attachment/adhesive compounds is of high interest in developing of ECL frameworks. This can increase the stability, sensitivity and functionality of the proposed bioassay. In this way, adhesive materials hold luminophores onto the electrode surface and prevent them from releasing (Wang et al. 2020; Bakshi et al. 2020). Nafion is an adhesive material for attachment of nano/biomaterials onto the surface of electrodes. High sensitivity and good signal stability are obtained in the consequence (Li et al. 2009; Bahari et al. 2020; Huang et al. 2020). Chitosan (CS) is another adhesive compound which is an appealing for its great characteristics. Unlike nafion, which is a class of synthetic polymers (Juliandri et al. 2018; Gluschke et al. 2021), CS is a biopolymer which make chitosan as a biocompatible and environmentally friendly material (Bakshi et al. 2020). There are some drawbacks in using of nafion for modification of electrodes. First, nafion is more expensive compared to the CS (Sigmaaldrich 2021a, b), second, in contrast of nafion, CS possess amine functional groups. This help to attach the antibody molecules onto the platform via amide bonds between their carboxylic groups and the amine functions of CS. Considering the fact that Abs are more arranged by attaching from their $-\mathrm{COOH}$ groups, $\mathrm{CS}$ is more appropriate by its ability to make covalent amide bonds with carboxylic ends of Abs.

To the best of our knowledge, there is no report documenting the combination of electrodeposited graphene nanosheets (GNSs) combined with chitosan and $\left[\mathrm{Ru}(\mathrm{bpy})_{3}\right]^{2+}$ for ECL diagnosis of BC. In this research, we aim to analysis of BC biomarker HER-2 by the ECL methodology enhanced by applying graphene nanomaterials. In this way, GNSs were electrochemically deposited onto the working electrode as supporting substrate. This deposition type led to more uniformity, stable and repeatable grafting of GNSs on the working electrode. 


\section{Methods}

\section{Reagents and procedures}

HER-2 protein (ab60866) and HER-2 antibody (Ab, ab214275) were purchased from Abcam company. The solution of HER-2 protein was provided by dissolving of the protein $(250 \mathrm{mg} / \mathrm{mL})$ in deionized water (DI). All the standard solutions used for calibration curve were provided by dilution of the source protein solution with DI. The $20 \mu \mathrm{g} / \mathrm{mL}$ of HER-2 Ab was used in all experiments.

All employed reagents were of high-pure grade and applied without any additional purification. Graphene oxide (GO) solution $(2 \mathrm{mg} / \mathrm{mL})$ and $\left[\mathrm{Ru}(\mathrm{bpy})_{3}\right]^{2+}$ were purchased from sigma Aldrich Company. Chitosan (CS) powder, tripropylamine (TPrA), acetic acid, sulfuric acid, nitric acid, $\mathrm{K}_{3}\left[\mathrm{Fe}(\mathrm{CN})_{6}\right], \mathrm{KCl}$ and EDC/NHS were acquired from Merck Company. HER-2 monoclonal antibody and its recombinant protein were obtained from Abcam Company. Phosphate buffer solutions (PBS) were prepared in room temperature and containing $\mathrm{KCl}(0.201 \mathrm{~g} / \mathrm{L}), \mathrm{NaCl}(8.000 \mathrm{~g} / \mathrm{L}), \mathrm{Na}_{2} \mathrm{HPO}_{4}(3.581 \mathrm{~g} / \mathrm{L}), \mathrm{KH}_{2} \mathrm{PO}_{4}$ $(0.231 \mathrm{~g} / \mathrm{L}), \mathrm{pH}=7.4$. The other $\mathrm{pH}$ values were prepared by addition of $3 \mathrm{~N}$ solutions of $\mathrm{NaOH}$ and $\mathrm{HCl}$. Chitosan solution was prepared by dissolving $0.1 \mathrm{mg}$ chitosan powder in $10 \mathrm{~mL}$ acetic acid/water solution $(1 \% \mathrm{v} / \mathrm{v})$. In order to prepare the $\left[\mathrm{Ru}(\mathrm{bpy})_{3}\right]^{2+}$ solution, $10 \mathrm{mg}\left[\mathrm{Ru}(\mathrm{bpy})_{3}\right]^{2+}$ powder was dissolved in $2 \mathrm{~mL} \mathrm{DI}$.

\section{Apparatus and electrodes}

Electrochemical records were implemented employing a Metrohm Autolab from Nova software. The analysis system included a triple-electrode system with a glassy carbon electrode (as working electrode, $3 \mathrm{~mm}$ in diameter), Pt wire electrode (as counter electrode) and an $\mathrm{Ag} / \mathrm{AgCl}$ (as reference electrode). All the detections, preparation of solutions, incubations, and deposition processes were performed in room temperature. An ultrasonic tool (Transsonic 420) was applied for surface cleaning of electrodes and suspending of solutions. A pH meter (Corning, 120) was used for adjusting the $\mathrm{pH}$ of $\mathrm{PBS}$ solutions. A magnetic stirrer model (Heidolph) was employed for mixing and preparation of all the solutions utilized in this study. A homemade ECL device was employed for ECL measurements (PMT, Hamamatsu, Japan). The ECL graphs were recorded by a homemade device coupled to autolab. The SEM images and semi-quantitative concentrations of the elements were obtained by TESCAN MIRA3, instrument.

\section{Fabrication of biosensing platform}

The working transducers were initially polished by using alumina powder (0.05 MICRON) to obtain mirror-like and clean surface. Then the electrode was ultrasonicated in water/acetone solution to eliminate the remaining materials on the electrode. Then, the electrode was electrochemically swept by immersing in $\mathrm{H}_{2} \mathrm{SO}_{4}$ solution $(0.5 \mathrm{M})$ in the range of 1 to $-1 \mathrm{~V}$. After dehumidify with nitrogen stream, the bare electrode was dipped in the GO solution $(0.1 \mathrm{mg} / \mathrm{mL})$ followed by scanning with cyclic voltammetry between -1.5 to $0.2 \mathrm{~V}(0.08 \mathrm{~V} / \mathrm{S})$ for 10 cycles. According to the literature (Ly et al. 2019; Zheng et al. 2015) GO is converted to its reduced form at much negative potentials around $-1 \mathrm{~V}$ vs $\mathrm{Ag} / \mathrm{Ag} \mathrm{Cl}$. Additional file 1: Figure S1A represents the reduction peak at about $-0.7 \mathrm{~V}$ vs $\mathrm{Ag} / \mathrm{AgCl}$ which can be correlated to the reduction of $\mathrm{GO}$ into rGO. The rGO modified electrode was placed into the deionized water for $10 \mathrm{~min}$ 
and dried in the incubator in the next. Afterward, the as prepared solutions of CS and $\left[\mathrm{Ru}(\mathrm{bpy})_{3}\right]^{2+}$ mixed (4:6, $\left.\mu \mathrm{L}: \mu \mathrm{L}\right)$ were drop-cast and incubated on the rGO-GCE for $2 \mathrm{~h}$ at ambient conditions $\left(25^{\circ} \mathrm{C}\right)$. Next, $5 \mu \mathrm{L}$ of EDC/NHS (2:1) was obtained from the previously prepared source solutions and added into the $5 \mu \mathrm{L}$ of Ab solution $(18 \mu \mathrm{g} / \mathrm{mL})$. The obtained solution was let to rest for $1 \mathrm{~h}$ to active the carboxylic groups of the $\mathrm{Ab}$ by EDC/NHS chemistry. The solution was then incubated onto the CS/[Ru(bpy $\left.)_{3}\right]^{2+} / \mathrm{rGO} /$ GCE for $2 \mathrm{~h}$. This led the Ab molecules to be immobilized onto the CS/[Ru(bpy $\left.)_{3}\right]^{2+} /$ rGO/GCE via amide bonds with amine groups of CS.

\section{ECL procedure}

In order to recognition of target protein, the prepared electrode surface was firstly treated by PBS solution ( $\mathrm{pH}=7.4$ ) for eliminating the unbound Abs. Then, different concentrations of HER-2 protein were incubated on the modified electrode. After incubating the modified electrode by various concentrations of HER-2 biomarker at laboratory temperature $\left(20{ }^{\circ} \mathrm{C}\right)$ for $2 \mathrm{~h}$, the framework was immersed into a mixture of TPrA/PBS $(2 \mathrm{~mL} / 8 \mathrm{~mL})$. The ECL evaluations were conducted by scanning in the range of 0.5 to $1.3 \mathrm{~V}\left(0.1 \mathrm{~V} \mathrm{~s}^{-1}\right)$ using $\mathrm{CV}$ technique and simultaneously recording the intensity of the emitted photons via ECL detector (PMT). During the determination process, the ECL cell containing all three electrodes was placed on the PMT and totally covered to avoid environmental photonic noise. The ECL readouts were recorded at $\lambda=450 \mathrm{~nm}$, correlating with the concentration of HER-2 protein.

\section{Results and discussion}

\section{Characterization of produced immunosensor}

As a proof of concept, the step-by-step modification and application of the proposed biosensor was characterized by CV, EIS and ECL techniques, and also with imaging methods like SEM and EDX.

\section{ECL investigation of the electrode modification steps}

At first, the effect of rGO as a main electrode modifier was studied (Fig. 1a, b). To this purpose, the ECL signals were measured in the presence and absence of rGO electrodeposition. The results showed very low ECL intensities in the absence of rGO electrodeposition which indicates the intense bleaching of the emitting materials. Furthermore, in the absence of the rGO, the ECL producing composite, chitosan and $\left[\mathrm{Ru}(\mathrm{bpy})_{3}\right]^{2+}$, was released from the electrode surface and the ECL signals are not stable. Also, the ECL characterization was depicted through obtaining ECL emission for step-by-step preparation of the developed ECL-based immunosensor (Fig. 2a and b). The results illustrated that the ECL intensity was decreased after incubation of Ab and the target HER-2 protein $(1 \mathrm{fM})$ which is in line with proofs. The decrease in the ECL readouts by Ab and target protein incubation resulted from the steric hindrance, which prevented the TPrA from reaching the electrode surface. This disrupts the reaction that results in ECL, ultimately reducing the intensity of ECL signals. 


\section{Morphological}

The morphological features of the electrode surface were investigated in different stages using SEM microscope. Figure 3a-f represents the SEM images correlated to the bare electrode (3A-C) and rGO modified electrode (3D-F) at different magnitudes (200, 500 and $1000 \mathrm{~nm}$ ). According to the SEM images, the rGO was electrodeposited in a proper manner on the bare electrode. The EDX patterns also indicated the presence of carbon and oxygen atoms after electrodeposition of the rGO, which represented the formation of oxygen groups onto the electrode. The quantitative elemental analysis is presented in Additional file 1: Table S1. As shown in Fig. 3d-f, the rGO was arranged is in a good quality.

\section{Proof of principle}

Benefiting the high conductivity, stability and desirable loading capacity of rGO along with high loading and adhesion capability of CS, the proposed biosensor provided a highly sensitive and stable biosensing assay. As shown in Additional file 1: Fig. S1B, the potential was screened from 0.5 to $1.3 \mathrm{~V}$ resulting an ECL pick current at about $0.75 \mathrm{~V}$. Correspondingly, the ECL emission is only appeared in the presence of TPrA which represent the background signals to be ignored. The mechanism for ECL of $\left[\mathrm{Ru}(\mathrm{bpy})_{3}\right]^{2+}$ could be established as follows (Liu et al. 2018; Workman and Richter 2000): both $\left[\mathrm{Ru}(\mathrm{bpy})_{3}\right]^{2+}$ and TPrA agents were oxidized on the surface of the electrode. This event appears as two oxidation peaks in the $\mathrm{CV}$ voltammograms at about 0.75 and $1.15 \mathrm{~V}$. TPrA is reacted with $\left[\mathrm{Ru}(\mathrm{bpy})_{3}\right]^{2+}$ after losing a proton to form an exited form of $\mathrm{Ru}(\mathrm{bpy})_{3}{ }^{2+^{*}}$. The product emits ECL light and relief into the ground state for further reaction cycles.

$$
\mathrm{Ru}(\mathrm{bpy})_{3}^{2+} \rightarrow \mathrm{Ru}(\mathrm{bpy})_{3}^{3+}+\mathrm{e}
$$
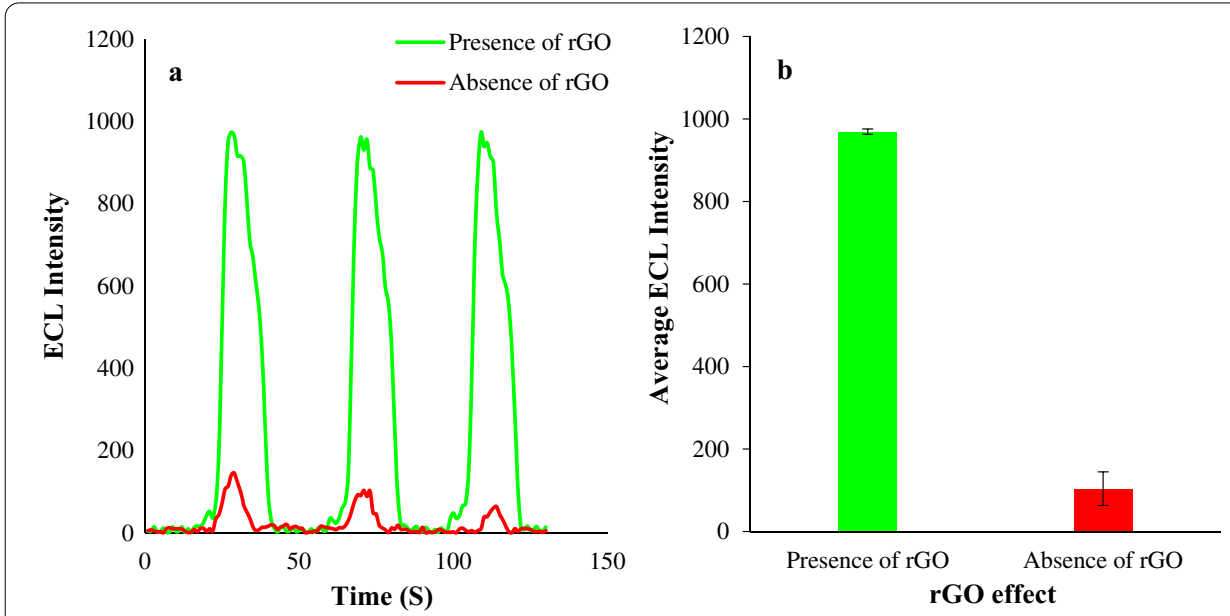

Fig. 1 The effect of $r G O$ on the intensity of $E C L$ signals. A) The three sequential ECL graphs, in the presence and absence of $\mathrm{rGO}$ with the same $\mathrm{CS}:\left[\mathrm{Ru}(\mathrm{bpy})_{3}\right]^{2+}$ mixture; B) corresponding histograms of average $\mathrm{ECL}$ intensity 

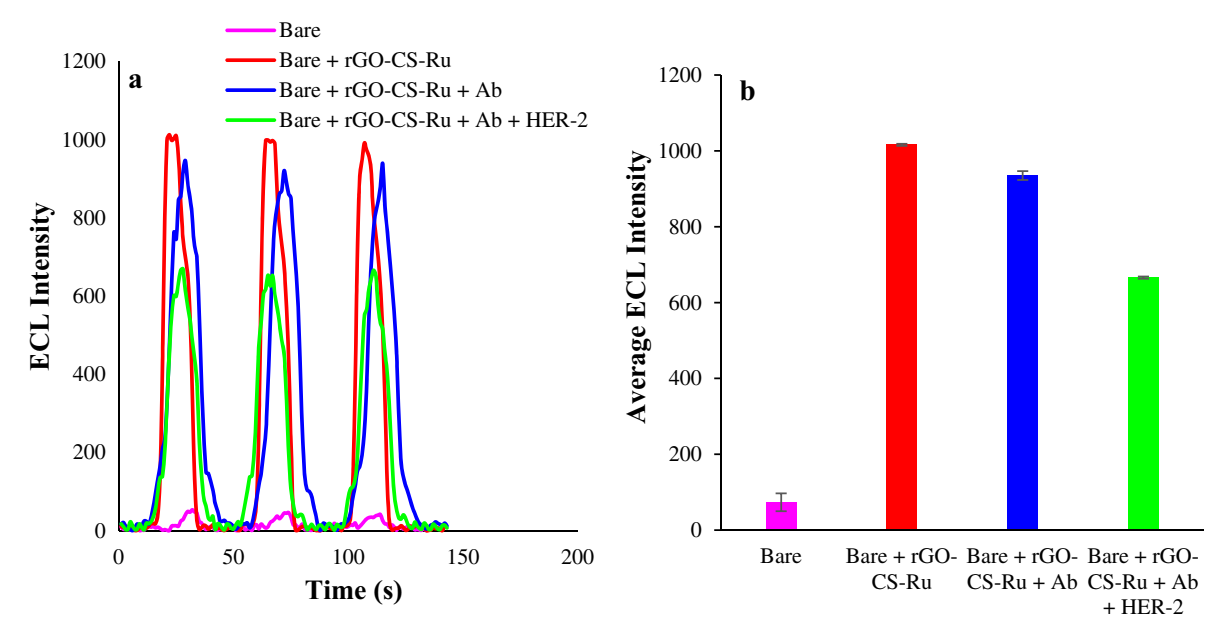

Fig. 2 Electrode preparation steps. a The three consecutive ECL graphs of Bare, Bare + rGO-CS-Ru, Bare $+r G O-C S-R u+A b$ and Bare $+r G O-C S-R u+A b+H E R-2 ; \mathbf{b}$ correlated histograms of average ECL intensity
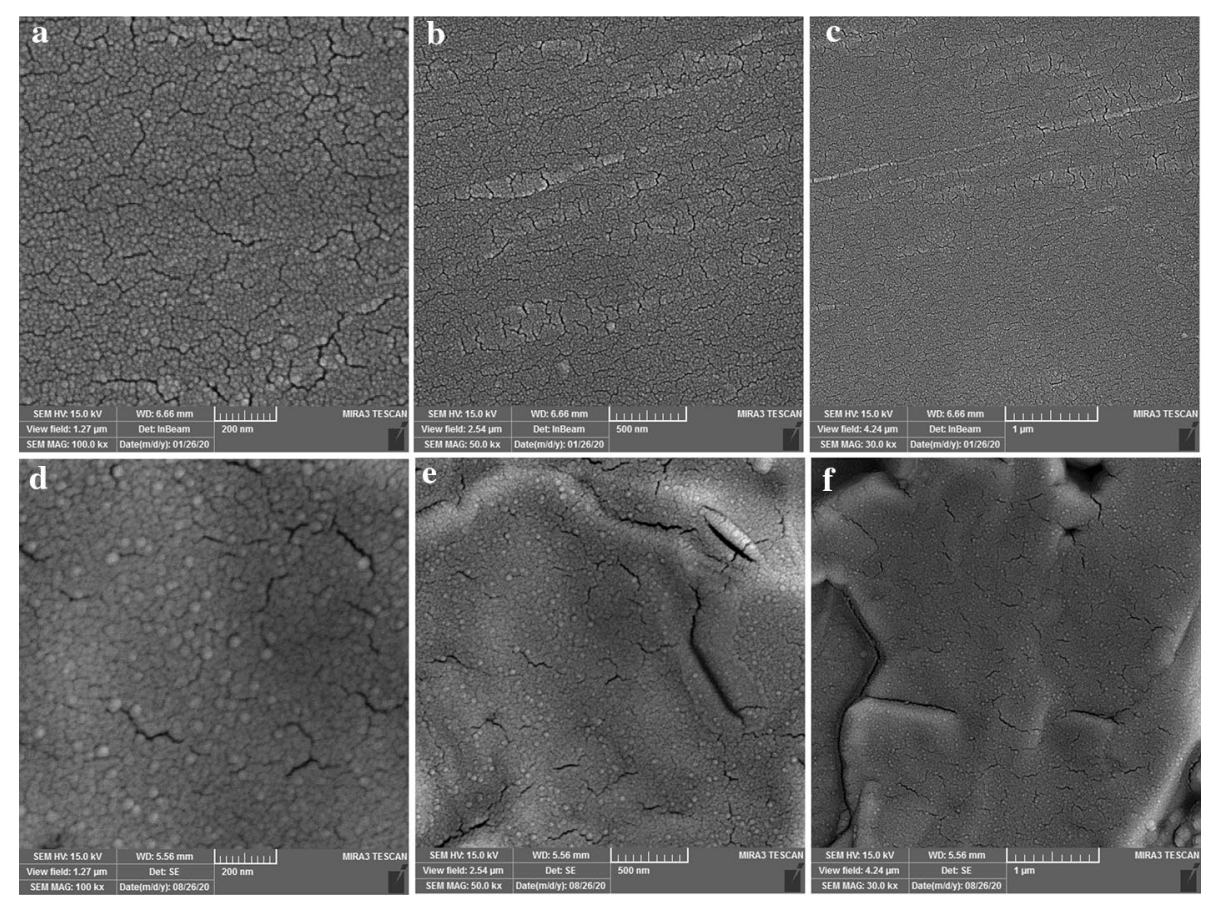

Fig. 3 The SEM images of the bare electrode $(\mathbf{a}, \mathbf{b}$ and $\mathbf{c})$ and $\mathrm{rGO}$ modified electrode $(\mathbf{d}, \mathbf{e}$ and $\mathbf{f})$ at different magnitudes of 200, 500 and $1000 \mathrm{~nm}$

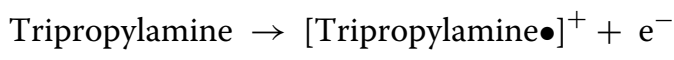

$[\text { Tripropylamine } \bullet]^{+} \rightarrow$ Tripropylamine ${ }^{\bullet}+\mathrm{H}^{+}$ 


$$
\begin{aligned}
& \operatorname{Ru}(\text { bpy })_{3}^{3+}+\text { Tripropylamine } \rightarrow \mathrm{Ru}(\text { bpy })_{3}^{2+*}+\mathrm{P} \\
& \operatorname{Ru}(\mathrm{bpy})_{3}^{2+*} \rightarrow \operatorname{Ru}(\text { bpy })_{3}^{2+}+\mathrm{h} v
\end{aligned}
$$

Looking at the ECL plots in Fig. 5, there is a shift doubling of ECL peaks by implementing mixed sample. This time-dependent shift is related to manual control of the ECL signal processing system. In this ECL instrument, the average signal intensity was applied as quantitative analysis of target protein. As a common rule, the ECL signals corresponded to a cyclic voltammetry technique, which was applied as electrochemical excitation of ECL source. In cyclic voltammetric procedures, the electroactive material in the cell, in this case TPrA, commonly shows a sharp oxidation peak and a lower intensity ECL peak in the reduction process. This doubling of the peaks corresponded to this phenomenon. This phenomenon is presented in some cases like in BSA peaks. Additionally, this process occurred in the other peaks with low intensities.

\section{Optimization of experimental conditions}

We optimized various experimental parameters to certify our protocol to be proceed in its highest efficiency. High sensitivity of ECL, bring it to be sensitized against environmental conditions. In this regard, different parameters were optimized in different modification stages. For rGO deposition, the number of electrodeposition cycles was optimized. According to Additional file 1: Fig. S2A and S2B, the best conductivity of the deposited rGO was gained in $10 \mathrm{CV}$ cycles from -1.5 to $0.2 \mathrm{~V}\left(0.08 \mathrm{~V} \mathrm{~s}^{-1}\right)$. It seems that by increasing the thickness of rGO on the electrode decrease the charge transferring capacity in the electrode-solution interface.

One of the important experimental factor in this study, as the ECL source, the CS/ $\left[\mathrm{Ru}(\mathrm{bpy})_{3}\right]^{2+}$ volume ratio was optimized. In this regard, the proposed protocol was implemented in different ratios of $\mathrm{CS} / \mathrm{Ru}(0: 5,2: 8,4: 6,5: 5,6: 4,8: 2)$. These volumes were used from the unique concentrations of $\mathrm{CS}$ and $\left[\mathrm{Ru}(\mathrm{bpy})_{3}\right]^{2+}$ solutions. The results indicated the best ECL for same volume ratio $(5 \mu \mathrm{L}: 5 \mu \mathrm{L})$. This ratio was adjusted for subsequent experiments. This optimization step is depicted in Additional file 1: Fig. S3A and S3B.

The temperature of electrode environment has also impact on the signal yields. It could affect the stability of the platforms, their interactions and affinities. In this regard, the platform was incubated in six different temperatures $\left(4,10,25,30,37\right.$ and $\left.45{ }^{\circ} \mathrm{C}\right)$. According to the results shown in Additional file 1: Fig. S4A and S4B, enhancement in the temperature leads to a rise in the ECL readouts up to room temperature $\left(25^{\circ} \mathrm{C}\right)$ and remain constant for further enhancements. So, the next experiments were performed at $25^{\circ} \mathrm{C}$.

As a vital parameter, incubation time of $\left[\mathrm{Ru}(\mathrm{bpy})_{3}\right]^{2+} / \mathrm{CS}$ mixture (as a ECL source) was also optimized. The results represented that increasing the incubation times caused the luminescence intensity to rise up to $2 \mathrm{~h}$, but more time had no enhancement effect on the signals $(0,30,60,90,120$ and $150 \mathrm{~min})$. The reason could be that increasing the incubation time gives the luminescence integration more time to make more positions inside the rGO network, and also stronger and stable interaction with CS (as supporter). 
So, at the following experiments incubation time was set as $2 \mathrm{~h}$. The resulted plots are indicated from Additional file 1: Fig. S5A and S5B.

In the following of factors' optimization process, we attempted to adjust the best concentration for coreactant (TPrA). This parameter was important from environmental and economic standpoint. First, the low usage of organic compounds, the reduction of harmful material release will be achieved. Second, the final cost will be decreased as low concentrations obtain as our optimum value. To this purpose, different TPrA/PBS ratios were examined (0.1:9.9, 0.5:9.5, 1:9, 1.5:8.5, 2:8, 3:7). According to the experiments, the best volume ratio of TPrA is find to be at 1.5:8.5. These results are presented in Additional file 1: Fig. S6A and S6B.

As can be seen previous section, $\mathrm{H}_{3} \mathrm{O}^{+}$is one of the species involved in ECL mechanism. So, optimization of $\mathrm{pH}$ range is of great significance for better conditions. In order to obtain the best $\mathrm{pH}$ range, 6 experiments were performed in different $\mathrm{pH}$ values (5, 7.2, 7.6, 8.2, 8.4, 9). The best result was fixed at moderate alkaline conditions $(\mathrm{pH}=8.2)$. According to the reactions, increasing the concentration of $\mathrm{H}_{3} \mathrm{O}^{+}$(low $\mathrm{pH}$ ) lead the $\mathrm{TPrA}^{*}$ to be converted into [TPrA $]^{+}$and lowered in the concentration which resulted in the lower ECL intensity. Also, it should be mentioned that CS is soluble in low $\mathrm{pH}$ ranges (lower than about 5.3) which can be another reason for low intensities in acidic conditions. The results of $\mathrm{pH}$ effect on the ECL intensity are illustrated in Additional file 1: Fig. S7A and S7B.

\section{Calibration curve}

The calibration curve was drawn measuring the ECL signal readouts for 7 concentrations of the HER-2 protein $(1,0.1,0.01,0.001,0.0001,0.00001,0.000001 \mathrm{nM})$. The LLOQ was practically obtained as $(0.000001 \mathrm{nM})$. According to the analytical definition, sensitivity was calculated as the slope of calibration curve. The more the slope of the curve, the more of sensitivity will be reachable. In this regard, the calibration equation was obtained as $Y=-45.233 \mathrm{X}+36.633$ and based on this equation, the sensitivity was gained as slope of calibration curve $(-45.233)$ which means the prepared system is a sensitive protocol for analyzing the HER-2 protein. The calibration curve and related ECL graphs are shown in Fig. 4a and b.

\section{Repeatability, reproducibility and stability investigations}

In order to test the within-lab precision of the analytical data, five freshly prepared ECL biosensors (HER-2 concentration: $0.001 \mathrm{nM}$ ) was examined in their responses. Recording $\mathrm{RSD}=3.1 \%$, the proposed immunosensor had an acceptable repeatability. The reproducibility of the biosensor, as an important factor of reliability, was also examined by preparing six different immunosensors (three electrodes in two concentrations of 0.001 and $0.00001 \mathrm{nM}$ ). The obtained RSDs of 3.15 and 3.5\% indicated the platform as a reproducible substrate for measuring purposes. The signal stability was also evaluated by calculating the RSD for 8 consecutive signal peaks in $1 \mathrm{fM}$ concentration of HER-2 protein (Fig. 5c). From the obtained RSDs, the framework provided a desirable signal stability during the analysis, consequently, no leakage of ECL source $\left[\mathrm{Ru}(\mathrm{bpy})_{3}\right]^{2+}$ was confirmed. Table 1 represents the analytical performance of the proposed nano-biosensing framework with the other related methods in evaluating the level of HER-2. Notice that the 
first two methods employed stripping voltammetry which a is more time-consuming methodology. Despite this fact, this work possesses a better LOD. The improved sensitivity could be viewed from several domains: first, the ECL method which is a highly sensitive one in the nature; second, the rGO film for its high surface area and conductivity, provided more and available sites for effectively holding of $\mathrm{CS} /\left[\mathrm{Ru}(\mathrm{bpy})_{3}\right]^{2+}$ composites onto the electrode. Using electrodeposition instead of simple incubation procedure lowered the preparation time and raised the signal stability and reproducibility. These are because of the uniform deposition of the rGO on the electrode, which might be the feature of the electrochemical deposition procedures. On the other hand, using CS as a biopolymer not only increases the stability of $\left[\mathrm{Ru}(\mathrm{bpy})_{3}\right]^{2+}$ on the $\mathrm{rGO} / \mathrm{GCE}$, but also provides amine functions to covalently attach $\mathrm{Ab}$ molecules. This led to further stability of the ECL signals.

\section{Selectivity}

To interpret the appealing level of the proposed nano-biosensor toward HER-2, the effect of three possible interferences (BSA, CA-15-3 and CEA) on ECL signals was investigated. A comparative study was performed and the results are illustrated in Fig. $5 \mathrm{a}$ and b. It is apparent that there was a low ECL readout on all the three interferences. However, the target protein (HER-2) and the mixture of the interferences within HER-2 (all in $0.1 \mathrm{ng} \mathrm{mL}$ ) resulted in a high ECL intensity.

\section{Real sample screening}

The practicality of the developed immunosensor was interpreted by analyzing the several real samples from different stages of the BC. The corresponding ECL graphs are depicted in Fig. $6 \mathrm{a}$ and b. In order to ascertain the credibility of the method, the results were compared to the pathological examinations. Pathological imaging revealed the existence of anaplastic changes indicated by the expression of HER-2 factors in the
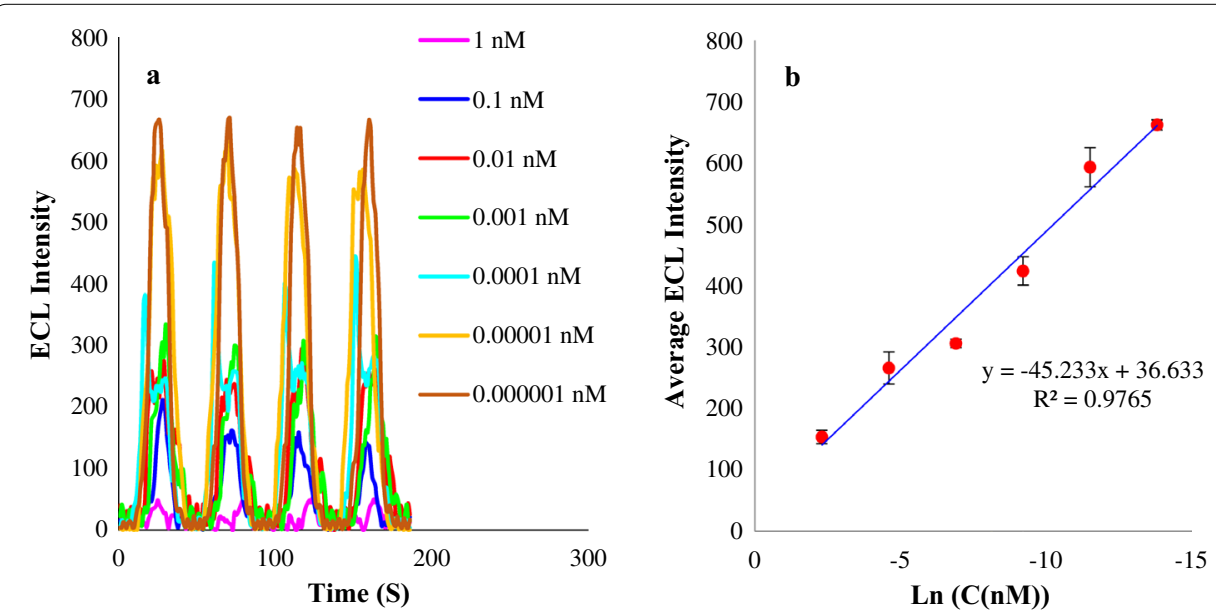

Fig. 4 a The ECL curves for GCE/rGO/CS-[Ru(bpy) $\left.]_{3}\right]^{2+} / \mathrm{Ab}-\mathrm{HER}-2$ in optimized conditions ( $\mathrm{pH}=8.2, \mathrm{PBS}$ solution, RT) for different concentrations of HER-2 protein $(0.000001,0.00001,0.0001,0.001,0.01,0.1$ and $1 \mathrm{nM})$; $\mathbf{b}$ calibration curve, the ECL intensity of final modified electrode at the corresponding concentrations of HER-2 protein 

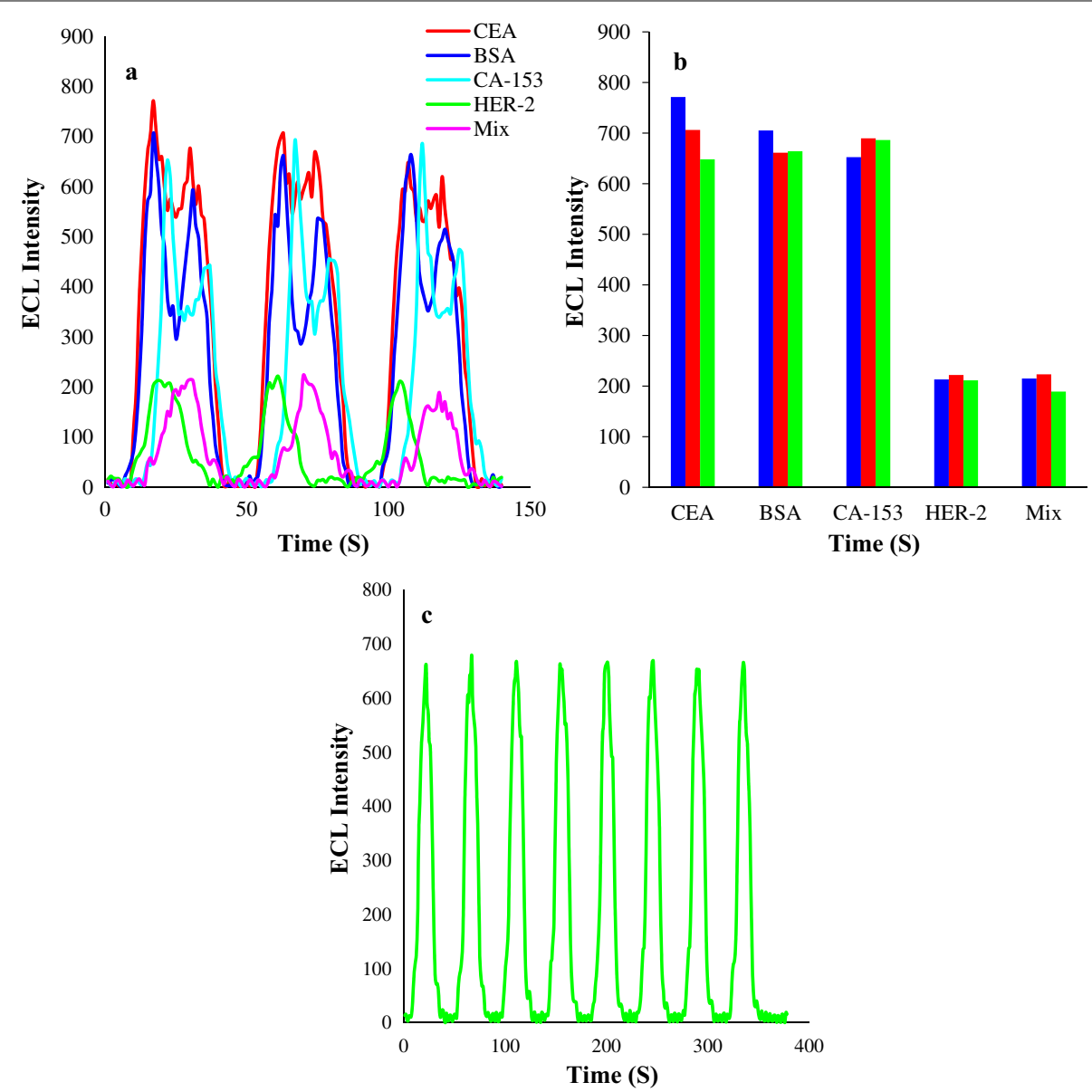

Fig. 5 a The ECL signals for the possible interferences: BSA, CA-15-3, CEA (0.1 $\mathrm{ng} \mathrm{mL})$ in the presence of HER-2 and mixture of them; $\mathbf{b}$ the related histograms for the selectivity of the proposed protocol for HER-2 quantification; $\mathbf{c}$ the stability of the designed biosensor in the presence of $1 \mathrm{fM}$ of HER-2 (during 8 repetitive evaluation)

target patients (Fig. 6c). Similar to the results obtained by the designed immunosensor, the anaplastic changes were in accordance to the signals intensity. These data showed that by increasing the malignancy and local expansion of cancer cells inside the breast tissue, the serum levels of HER-2 factor were also heightened, showing a close relationship between the anaplastic changes and recorded ECL signals. These data show that our sophisticated modality is also eligible to diagnose the severity and progression of breast cancers, which is critical in cancer candidates. Like the previous studies, it was noticed that the HER-2 factor is released to the systemic circulation. Regarding the notable sensitivity of developed method, one can hypothesize that the current strategy is helpful in an early-stage detection of anaplastic changes soon after the cancer formation. It is important to declare that, the real samples were desirably analyzed without any treatment, in other words, the serum samples were evaluated in unprocessed forms. The signals intensity and the calculated concentrations of HER-2 protein are represented in Table 2. The concentration measures were calculated via the obtained calibration curve 
Table 1 The comparison of the proposed ECL protocol with other strategies for HER-2 determination

\begin{tabular}{|c|c|c|c|c|c|}
\hline $\begin{array}{l}\text { Detection } \\
\text { technique }\end{array}$ & $\begin{array}{l}\text { Employed } \\
\text { technique }\end{array}$ & Employed materials & LOD & LDR & Refs. \\
\hline EC & $\begin{array}{l}\text { DPV (anodic } \\
\text { striping vol- } \\
\text { tammetry) }\end{array}$ & Fe3O4-Au NPs-AgNPs & $20 \mathrm{fg} / \mathrm{mL}$ & $\begin{array}{l}0.0005-50 \mathrm{ng} / \\
\mathrm{mL} \\
0.0005-50 \mathrm{ng} / \\
\mathrm{mL}\end{array}$ & $\begin{array}{l}\text { Shamsipur } \\
\text { et al. (2018) }\end{array}$ \\
\hline EC & $\begin{array}{l}\text { Anodic stripping } \\
\text { voltammetry }\end{array}$ & $\begin{array}{l}\mathrm{GrNSs}^{\mathrm{a}} \\
\mathrm{CdSe} \mathrm{QDs}\end{array}$ & $\begin{array}{l}100 \mathrm{fg} / \mathrm{mL} \text { and } \\
1 \mathrm{pg} / \mathrm{mL} \\
\text { in PBS and } \\
\text { serum }\end{array}$ & $\begin{array}{l}0.0001-0.1 \text { and } \\
0.1-10,000 \mathrm{ng} / \\
\mathrm{mL}\end{array}$ & $\begin{array}{l}\text { Shiddiky et al. } \\
\text { (2012) }\end{array}$ \\
\hline EC & $\begin{array}{l}\text { EIS } \\
\text { DPV }\end{array}$ & $\mathrm{TiO} 2$ nanofibers & $185 \mathrm{fg} / \mathrm{mL}$ & $\begin{array}{l}1.0 \mathrm{fM}-0.1 \mu \mathrm{M} \\
\text { for EIS } \\
0.1 \mathrm{pM}-0.1 \mu \mathrm{M} \\
\text { for DPV }\end{array}$ & $\begin{array}{l}\text { Ali et al. } \\
\text { (2016) }\end{array}$ \\
\hline EC & EIS & ZnO nanofibers & $185 \mathrm{fg} / \mathrm{mL}$ & $1.0 \mathrm{fM}-0.5 \mu \mathrm{M}$ & $\begin{array}{l}\text { Ali et al. } \\
\text { (2015) }\end{array}$ \\
\hline EC & SWV & Au NPs & $0.5 \mathrm{pg} / \mathrm{mL}$ & $\begin{array}{l}1 \mathrm{pg} / \mathrm{mL} \text { to } 1 \mathrm{ng} / \\
\mathrm{mL}\end{array}$ & Li et al. (2018) \\
\hline EC & DPV & $\begin{array}{l}\mathrm{Fe} 3 \mathrm{O} 4 \mathrm{NPs} \\
\mathrm{Au} N \mathrm{NPS}\end{array}$ & $0.995 \mathrm{pg} / \mathrm{mL}$ & $\begin{array}{l}0.01-10 \text { and } \\
10-100 \mathrm{ng} / \mathrm{mL}\end{array}$ & $\begin{array}{l}\text { Emami et al. } \\
(2014)\end{array}$ \\
\hline EC & Amperometry & Au NPs & $12 \mathrm{pg} \mathrm{mL}$ & $0.001-10 \mathrm{ng} / \mathrm{mL}$ & $\begin{array}{l}\text { Carvajal et al. } \\
\text { (2018) }\end{array}$ \\
\hline EC & Impedimetric & Au NPs & $0.01 \mathrm{ng} / \mathrm{mL}$ & $0.01-100 \mathrm{ng} / \mathrm{mL}$ & $\begin{array}{l}\text { Sharma et al. } \\
\text { (2018) }\end{array}$ \\
\hline Colorimetric & & AuNPs & $10 \mathrm{nM}$ & $0 \mathrm{M}-99 \mathrm{nM}$ & $\begin{array}{r}\text { Ranganathan } \\
\text { et al. (2020) }\end{array}$ \\
\hline Optical & Fluorescent & $\mathrm{Ag} \mathrm{NCs^{b }}$ & $0.0904 \mathrm{fM}$ & $8.5 \mathrm{fM}$ to $225 \mathrm{fM}$ & $\begin{array}{l}\text { Zhang et al. } \\
\text { (2019) }\end{array}$ \\
\hline Piezoelectric & & & $0.0253 \mathrm{ng} / \mathrm{mL}$ & 0 to $3 \mathrm{ng} / \mathrm{mL}$ & $\begin{array}{l}\text { Loo et al. } \\
\quad(2011)\end{array}$ \\
\hline $\mathrm{ECL}$ & $\mathrm{ECL}$ & {$\left[\mathrm{Ru}(\mathrm{bpy})_{3}\right]^{2+}$} & $1 \mathrm{fM}$ & $1 \mathrm{fM}$ to $1 \mathrm{nM}$ & This project \\
\hline
\end{tabular}

${ }^{a}$ Graphene nanosheets

${ }^{\mathrm{b}}$ Silver nanoclusters

$(\mathrm{Y}=-45.233 \mathrm{X}+36.633)$, where $\mathrm{X}$ and $\mathrm{Y}$ are concentration amount of the HER-2 for the ECL intensity for each real sample.

\section{Conclusion}

In this research, we designed an ultrasensitive ECL immunosensing framework for determination of HER-2 protein biomarker in serum samples. In this regard, $\left[\mathrm{Ru}(\mathrm{bpy})_{3}\right]^{2+} /$ TPrA was used as anodic ECL system. We employed electrodeposition method for uniform layer of rGO on the electrode. Using CS (as biocompatible polymer), the $\mathrm{Ab}$ molecules were strongly attached on the electrode via amide bounds.Consequently, the method indicated a good stability and reproducibility. Using rGO and CS increase the loading capacity for biorecognition elements (Abs) leading to a desirable LLOQ of $1 \mathrm{fM}$. After proving the high selectivity of the protocol for the target protein, the method was employed for analysis of real samples. Acquired results represented a good detection capability of the immunosensor for applying in clinical domains. Regarding the biocompatibility of the all employed materials in construction of the proposed nano-biosensor, the developed platform can be used in in vivo diagnosis tools. 

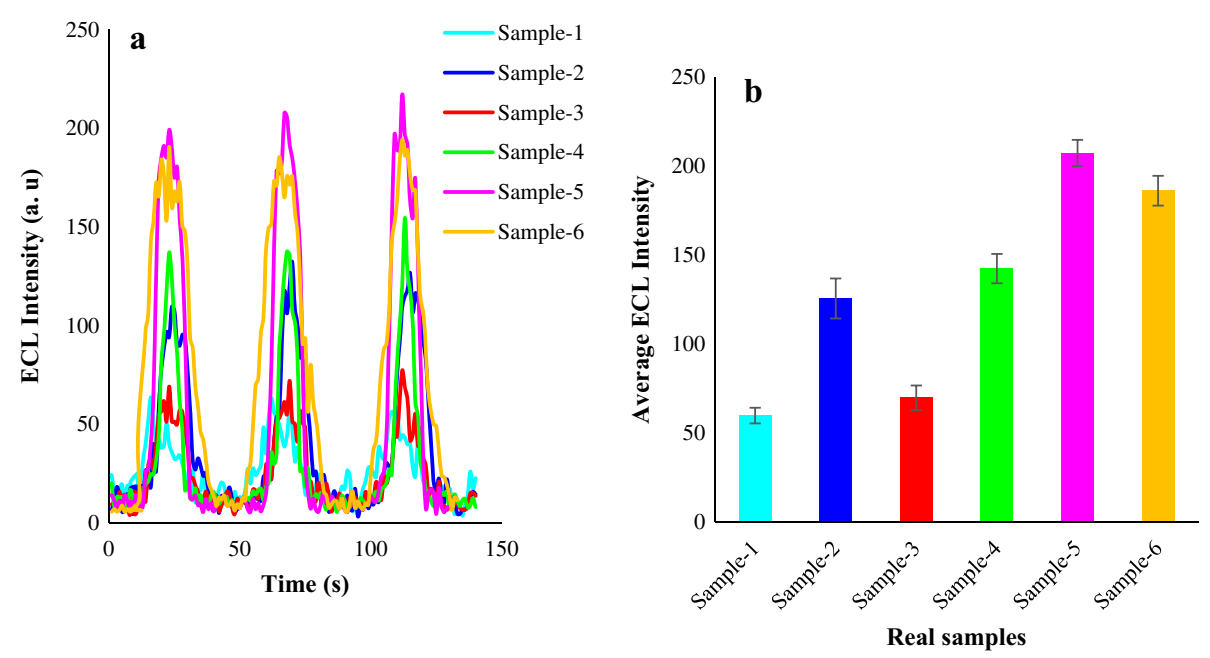

c
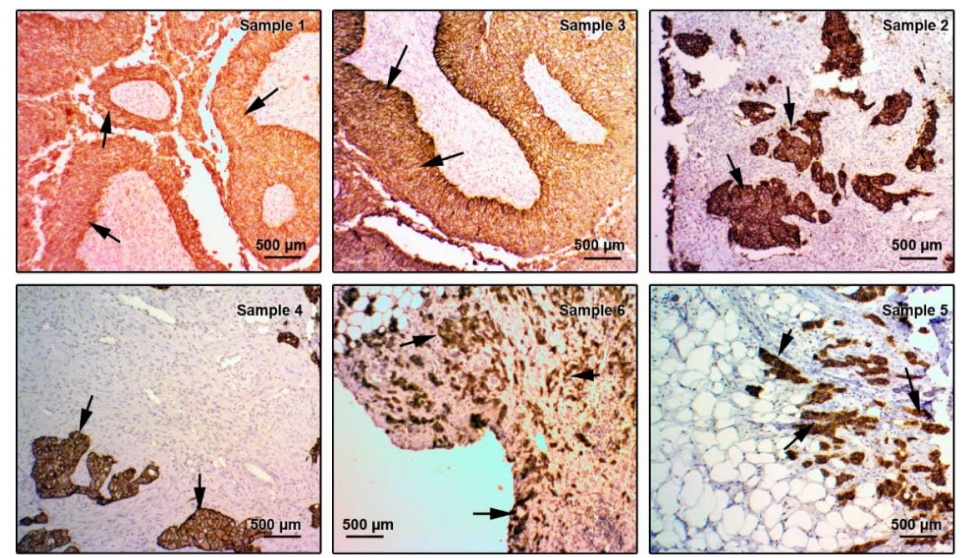

Fig. 6 Identification of the HER-2 in untreated serum samples from breast cancer patients. a The ECL plots; $\mathbf{b}$ the correlated histograms. The error bares were obtained by three ECL measurements for each sample and $\mathbf{c}$ immunohistochemical imaging of breast samples in cancer patients. The HER-2 positive cells were indicated by the black arrows (brown-colored cells)

Table 2 The calculated concentrations for each HER-2-positive real sample using the proposed method

\begin{tabular}{lcl}
\hline Sample number & Average ECL intensity & $\begin{array}{l}\text { The calculated } \\
\text { concentration } \\
\text { (nM) }\end{array}$ \\
\hline Sample 1 & 59.725 & 0.600 \\
Sample 2 & 125.550 & 0.140 \\
Sample 3 & 69.675 & 0.481 \\
Sample 4 & 142.375 & 0.096 \\
Sample 5 & 207.375 & 0.023 \\
Sample 6 & 186.20 & 0.036 \\
\hline
\end{tabular}




\section{Supplementary Information}

The online version contains supplementary material available at https://doi.org/10.1186/s12645-021-00082-y.

Additional file 1: Table S1. Quantitative elemental analysis of $\mathrm{rGO}$ deposited GCE using EDX. Figure S1. A) Cyclic voltammogram of electrodeposition process of rGO; B) Cyclic voltammogram of final modified electrode which was recorded in the optimum experimental conditions. Figure S2. The optimization of $\mathrm{rGO}$ cycle number on the ECL intensities. A) The ECL curves for different cycle numbers of $\mathrm{rGO}(5,10,15,20,25)$ in $\mathrm{GO}$ solution $(0.2 \mathrm{mg} \mathrm{mL}-1)$ $(\mathrm{pH}=8.5)$ with the same amount of CS:Ru mixture; B) The corresponding histograms, extracted from average $\mathrm{ECL}$ curves $(n=3)$. Figure S3. Optimization of CS:Ru ration, A) The ECL curves for different proportions of CS/ Ru[(bpy)3] $(0: 5,2: 8,4: 6,6: 4,8: 2$, CS:Ru); B) the ECL signal readouts for the proposed ratios of CS/ Ru[(bpy)3]. Figure S4. Optimization of incubation temperature of CS:Ru on the rGO modified GCE. A) The ECL plots for different temperatures of incubation $\left.\left(4,10,25,30,37,45^{\circ} \mathrm{C}\right) ; \mathrm{B}\right)$ the related mean intensities. All the $\mathrm{ECL}$ measurements are obtained in PBS solutions $(\mathrm{pH}=8)$ and previously optimized parameters. Figure $\mathrm{S} 5$. Optimization of incubation time of CS:Ru on the $\mathrm{rGO}$ modified $\mathrm{GCE}$ at $25^{\circ} \mathrm{C}$. A) Effect of incubation time on $\mathrm{ECL}$ peak height $(0,30,60,90,120,150$ minutes); B) the average ECL peak values obtained in different incubation times. Figure S6. Optimization of TPrA concentration: A) ECL signal readouts were obtained for different levels of TPrA in PBS solution ( $\mathrm{pH}=8,25^{\circ} \mathrm{C}$ and $120 \mathrm{~min}$ ); B) the related mean peak intensities of each point. Figure S7. Optimization of pH level. A) ECL plots obtained in PBS solutions at different $\mathrm{pHs}(5,7.2,7.6,8.2,8.6,9)$; B) the correlated average signal intensities for each $\mathrm{pH}$ values. The experiments are performed in previously optimized conditions $\left(25^{\circ} \mathrm{C}, 120 \mathrm{~min}\right.$ and $\left.1.5 \mathrm{~mL} \operatorname{TPr}\right)$.

\section{Acknowledgements}

This project (Grant Number: 973631) was financially supported by national institute of medical research development (NIMAD) and ethically approved by National Committee for Ethics in Biomedical Research, IR.NIMAD.REC.1397.531.

\section{Authors' contributions}

HN was contributed in all experimental analysis and prepared first draft. BK was supervised the study, participated in idea, design and development of the method, validation of data, writing and editing. Professor II participated in validation of data and editing. Professor M-RR contributed in study design and data interpretations. EAH performed surgical procedures and sampling. AN supervised the study and helped in data analysis and editing. All authors read and approved the final manuscript.

\section{Funding}

National institute of medical research development (NIMAD): Grant Number: 973631.

\section{Availability of data and materials}

Not applicable.

\section{Declarations}

Ethics approval and consent to participate

All phases of this study were approved by National Committee for Ethics in Biomedical Research (IR.NIMAD. REC.1397.531). Prior to sampling, all patients were requested to fill informed consent.

\section{Consent for publication}

Not applicable.

\section{Competing interests}

The authors declare no competing interest.

\section{Author details}

'Department of Analytical Chemistry, Faculty of Chemistry, University of Tabriz, PO Box 51644-14766, Tabriz, Iran.

${ }^{2}$ Department of Bioengineering, Faculty of Chemistry-Metallurgy, Yildiz Technical University, 34220 Istanbul, Turkey.

${ }^{3}$ Research Center for Pharmaceutical Nanotechnology (RCPN), Tabriz University of Medical Sciences, Tabriz, Iran. ${ }^{4}$ Clinical Research Department, Breast Cancer Research Center, Motamed Cancer Institute, ACECR, Tehran, Iran. ${ }^{5}$ Stem Cell Research Center, Tabriz University of Medical Sciences, 51664-14766 Tabriz, Iran.

Received: 10 January 2021 Accepted: 22 April 2021

Published online: 01 May 2021

\section{References}

Ali MA, Mondal K, Singh C, Malhotra BD, Sharma A. Anti-epidermal growth factor receptor conjugated mesoporous zinc oxide nanofibers for breast cancer diagnostics. Nanoscale. 2015;7(16):7234-45. https://doi.org/10.1039/c5nr00194c

Ali MA, Mondal K, Jiao Y, Oren S, Xu Z, Sharma A, Dong L. Microfluidic immuno-biochip for detection of breast cancer biomarkers using hierarchical composite of porous graphene and titanium dioxide nanofibers. ACS Appl Mater Interfaces. 2016;8(32):20570-82. https://doi.org/10.1021/acsami.6b05648.

Babaei A, Zendehdel M, Khalilzadeh B, Abnosi M. A new sensor for simultaneous determination of tyrosine and dopamine using iron (III) doped zeolite modified carbon paste electrode. Chin J Chem. 2010;28(10):1967-72. 
Bahari D, Babamiri B, Salimi A, Hallaj R, Amininasab SMJACA. A self-enhanced ECL-RET immunosensor for the detection of CA19-9 antigen based on Ru (bpy) 2 (phen-NH2) 2+-Amine-rich nitrogen-doped carbon nanodots as probe and graphene oxide grafted hyperbranched aromatic polyamide as platform. Anal Chim Acta. 2020;1132:55-65.

Bakshi PS, Selvakumar D, Kadirvelu K, Kumar NS. Chitosan as an environment friendly biomaterial-a review on recent modifications and applications. Int J Biol Macromol. 2020;150:1072-83.

Cao H, Dan Z, He X, Zhang Z, Yu H, Yin Q, Li Y. Liposomes coated with isolated macrophage membrane can target lung metastasis of breast cancer. ACS Nano. 2016;10(8):7738-48. https://doi.org/10.1021/acsnano.6b03148.

Carvajal S, Fera SN, Jones AL, Baldo TA, Mosa IM, Rusling JF, Krause CE. Disposable inkjet-printed electrochemical platform for detection of clinically relevant HER-2 breast cancer biomarker. Biosens Bioelectron. 2018;104:158-62. https://doi. org/10.1016/j.bios.2018.01.003.

De Oliveira RA, Nicoliche CY, Pasqualeti AM, Shimizu FM, Ribeiro IR, Melendez ME, Carvalho AL, Gobbi AL, Faria RC, Lima RS. Low-cost and rapid-production microfluidic electrochemical double-layer capacitors for fast and sensitive breast cancer diagnosis. Anal Chem. 2018;90(21):12377-84.

Dong Y-P, Chen G, Zhou Y, Zhu JJ. Electrochemiluminescent sensing for caspase-3 activity based on Ru (bpy) 32+-doped silica nanoprobe. Anal Chem. 2016;88(3):1922-9.

Emami M, Shamsipur M, Saber R, Irajirad R. An electrochemical immunosensor for detection of a breast cancer biomarker based on antiHER2-iron oxide nanoparticle bioconjugates. Analyst. 2014;139(11):2858-66. https://doi.org/10.1039/ c4an00183d.

Fang D, Ren H, Huang Y, Dai H, Huang D, Lin YJS, Chemical AB. Photothermal amplified cathodic ZnO quantum dots/Ru (bpy) 32+/S2O82-ternary system for ultrasensitive electrochemiluminescence detection of thyroglobulin. Sensors Actuators B Chem. 2020;312:127950.

Gluschke J, Seidl J, Lyttleton R, Nguyen K, Lagier M, Meyer F, Krogstrup P, Nygård J, Lehmann S, Mostert AJMH. Integrated bioelectronic proton-gated logic elements utilizing nanoscale patterned Nafion. Mater Horizons. 2021;8(1):224-33.

Guo Q, Li X, Shen C, Zhang S, Qi H, Li T, Yang M. Electrochemical immunoassay for the protein biomarker mucin 1 and for MCF-7 cancer cells based on signal enhancement by silver nanoclusters. Microchim Acta. 2015;182(7-8):1483-9.

Hatamzadeh M, Jaymand M. Synthesis of conductive polyaniline-modified polymers via a combination of nitroxidemediated polymerization and "Click chemistry." RSC Adv. 2014;4(54):28653-63.

Huang CH, Park YI, Lin HY, Pathania D, Park KS, Avila-Wallace M, Castro CM, Weissleder R, Lee H. Compact and filter-free luminescence biosensor for mobile in vitro diagnoses. ACS Nano. 2019. https://doi.org/10.1021/acsnano.9b05634.

Huang B, Yao C, Zhang Y, Lu XJT. A novel label-free solid-state electrochemiluminescence sensor based on the resonance energy transfer from Ru (bpy) 32+ to GO for DNA hybridization detection. Talanta. 2020;218:121126.

Juliandri J, Rukiah R, Ernawati E, Handika R, Nasir MJWSN. Nanocomposite sulfonated PVDF-TiO2 membranes as a potential alternative for nafion. World Sci News. 2018;107:150-9.

Kalaiyarasan G, Raju CV, Veerapandian M, Kumar SS, Joseph JJA. Impact of aminated carbon quantum dots as a novel coreactant for Ru (bpy) $32+$ : resolving specific electrochemiluminescence for butein detection. Anal bioanal Chem. 2020;412(3):539-46.

Karim-Nezhad G, Hasanzadeh M, Saghatforoush L, Shadjou N, Khalilzadeh B, Ershad S. Electro-oxidation of ascorbic acid catalyzed on cobalt hydroxide-modified glassy carbon electrode. J Serb Chem Soc. 2009;74(5):581-93.

Khalilzadeh B, Hasanzadeh M, Sanati S, Saghatforoush L, Shadjou N, Dolatabadi JEN, Sheikhzadeh P. Preparation of a new electrochemical sensor based on cadmium oxide nanoparticles and application for determination of penicillamine. Int J Electrochem Sci. 2011;6:4164-75.

Khalilzadeh B, Shadjou N, Charoudeh HN, Rashidi M-R. Recent advances in electrochemical and electrochemiluminescence based determination of the activity of caspase-3. Microchim Acta. 2017;184(10):3651-62.

Kilic T, Topkaya SN, Ariksoysal DO, Ozsoz M, Ballar P, Erac Y, Gozen O. Electrochemical based detection of microRNA, mir21 in breast cancer cells. Biosens Bioelectron. 2012;38(1):195-201.

Kitte SA, Gao W, Zholudov YT, Qi L, Nsabimana A, Liu Z, Xu G. Stainless steel electrode for sensitive luminol electrochemiluminescent detection of H2O2, glucose, and glucose oxidase activity. Anal Chem. 2017;89(18):9864-9.

Li H, Chen J, Han S, Niu W, Liu X, Xu G. Electrochemiluminescence from tris(2,2'-bipyridyl)ruthenium(II)-graphene-Nafion modified electrode. Talanta. 2009;79(2):165-70. https://doi.org/10.1016/j.talanta.2009.03.020.

Li Y, Schluesener HJ, Xu S. Gold nanoparticle-based biosensors. Gold Bull. 2010;43(1):29-41.

$\mathrm{Li} \mathrm{H}, \mathrm{He}$ J, Li S, Turner AP. Electrochemical immunosensor with N-doped graphene-modified electrode for label-free detection of the breast cancer biomarker CA 15-3. Biosens Bioelectron. 2013;43:25-9. https://doi.org/10.1016/j.bios. 2012.11.037.

Li L, Chen Y, Zhu J-JJAC, . Recent advances in electrochemiluminescence analysis. Anal Chem. 2017;89(1):358-71.

Li X, Shen C, Yang M, Rasooly A. Polycytosine DNA electric-current-generated immunosensor for electrochemical detection of human epidermal growth factor receptor 2 (HER2). Anal Chem. 2018;90(7):4764-9. https://doi.org/10.1021/ acs.analchem.8b00023.

Liu Z, Qi W, Xu GJCSR. Recent advances in electrochemiluminescence. Chem Soc Rev. 2015;44(10):3117-42.

Liu C, Hou J, Waterhouse GIN, Cui L, Dong J, Ai S. A novel pH-responsive electrochemiluminescence immunosensor for ALV-J detection based on hollow MnO2 encapsulating Ru(bpy)3Cl2. Biosens Bioelectron. 2018;1 18:167-73. https:// doi.org/10.1016/j.bios.2018.07.040.

Loo L, Capobianco JA, Wu W, Gao X, Shih WY, Shih W-H, Pourrezaei K, Robinson MK, Adams GP. Highly sensitive detection of HER2 extracellular domain in the serum of breast cancer patients by piezoelectric microcantilevers. Anal Chem. 2011;83(9):3392-7.

Luo X, Morrin A, Killard AJ, Smyth MR. Application of nanoparticles in electrochemical sensors and biosensors. Electroanal Int J Devoted Fundam Pract Aspects Electroanal. 2006;18(4):319-26.

Lv Y, Chen S, Shen Y, Ji J, Zhou Q, Liu S, Zhang Y. Competitive multiple-mechanism-driven electrochemiluminescent detection of 8-hydroxy-2'-deoxyguanosine. J Am Chem Soc. 2018;140(8):2801-4.

Ly CT, Phan CT, Vu CN, Le HS, Nguyen TT, Le LA, Vu TT. Electrodeposition of PEDOT-rGO film in aqueous solution for detection of acetaminophen in traditional medicaments. Adv Nat Sci Nanosci Nanotechnol. 2019;10(1):015013. 
Mansor NA, Zain ZM, Hamzah HH, Noorden MSA, Jaapar SS, Beni V, Ibupoto ZH. Detection of breast cancer 1 (BRCA1) gene using an electrochemical DNA biosensor based on immobilized $\mathrm{ZnO}$ nanowires. Open J Appl Biosens. 2014;3(02):9.

Massoumi B, Aali N, Jaymand M. Novel nanostructured star-shaped polyaniline derivatives and their electrospun nanofibers with gelatin. RSC Adv. 2015;5(130):107680-93.

Min J, Im H, Allen M, McFarland PJ, Degani I, Yu H, Normandin E, Pathania D, Patel JM, Castro CM, Weissleder R, Lee H. Computational optics enables breast cancer profiling in point-of-care settings. ACS Nano. 2018;12(9):9081-90. https://doi.org/10.1021/acsnano.8b03029.

Nakhjavani SA, Afsharan H, Khalilzadeh B, Ghahremani MH, Carrara S, Omidi Y. Gold and silver bio/nano-hybrids-based electrochemical immunosensor for ultrasensitive detection of carcinoembryonic antigen. Biosens Bioelectron. 2019;141:111439.

Nasrollahpour H, Mahdipour M, Isildak I, Rashidi M-R, Naseri A, Khaliizadeh B. A highly sensitive electrochemiluminescence cytosensor for detection of SKBR-3 cells as metastatic breast cancer cell line: a constructive phase in early and precise diagnosis. Biosens Bioelectron. 2021;178:113023.

Nawaz M, Rauf S, Catanante G, Nawaz M, Nunes G, Marty J, Hayat A. One step assembly of thin films of carbon nanotubes on screen printed interface for electrochemical aptasensing of breast cancer biomarker. Sensors. 2016;16(10):1651.

Ranganathan V, Srinivasan S, Singh A, DeRosa MC. An aptamer-based colorimetric lateral flow assay for the detection of human epidermal growth factor receptor 2 (HER2). Anal Biochem. 2020;588:113471.

Reta N, Saint CP, Michelmore A, Prieto-Simon B, Voelcker NH. Nanostructured electrochemical biosensors for label-free detection of water- and food-borne pathogens. ACS Appl Mater Interfaces. 2018;10(7):6055-72. https://doi.org/10. 1021/acsami.7b13943.

Richter MM. Electrochemiluminescence (ecl). Chem Rev. 2004;104(6):3003-36.

Saghatforoush L, Hasanzadeh M, Karim-Nezhad G, Ershad S, Shadjou N, Khalilzadeh B, Hajjizadeh M. Kinetic study of the electrooxidation of mefenamic acid and indomethacin catalysed on cobalt hydroxide modified glassy carbon electrode. Bull Korean Chem Soc. 2009;30(6):1341-8.

Sanvicens N, Pastells C, Pascual N, Marco M-P. Nanoparticle-based biosensors for detection of pathogenic bacteria. TrAC, Trends Anal Chem. 2009;28(11):1243-52.

Shamsipur M, Emami M, Farzin L, Saber R. A sandwich-type electrochemical immunosensor based on in situ silver deposition for determination of serum level of HER2 in breast cancer patients. Biosens Bioelectron. 2018;103:54-61. https://doi.org/10.1016/j.bios.2017.12.022.

Sharma S, Zapatero-Rodriguez J, Saxena R, O'Kennedy R, Srivastava S. Ultrasensitive direct impedimetric immunosensor for detection of serum HER2. Biosens Bioelectron. 2018;106:78-85. https://doi.org/10.1016/j.bios.2018.01.056.

Shiddiky MJ, Rauf S, Kithva PH, Trau M. Graphene/quantum dot bionanoconjugates as signal amplifiers in stripping voltammetric detection of EpCAM biomarkers. Biosens Bioelectron. 2012;35(1):251-7. https://doi.org/10.1016/j.bios. 2012.02.057.

Sigmaaldrich (2021) https://www.sigmaaldrich.com/catalog/product/aldrich/448869?lang=en\&region=IR.

Sigmaaldrich (2021) sigmaaldrich.com/catalog/product/aldrich/274674?lang=en\&region=IR.

Tang Y, Dai Y, Huang X, Li L, Han B, Cao Y, Zhao J. Self-assembling peptide-based multifunctional nanofibers for electrochemical identification of breast cancer stem-like cells. Anal Chem. 2019;91(12):7531-7. https://doi.org/10.1021/acs. analchem.8b05359.

Truong CKP, Nguyen TDD, Shin I-S. Electrochemiluminescent chemosensors for clinical applications: a review. Biochip J. 2019;13(3):203-16.

Wang T, Zhang S, Mao C, Song J, Niu H, Jin B, Tian Y. Enhanced electrochemiluminescence of CdSe quantum dots composited with graphene oxide and chitosan for sensitive sensor. Biosens Bioelectron. 2012;31(1):369-75. https://doi. org/10.1016/j.bios.2011.10.048.

Wang Y, Garcia CR, Ding Z, Gabrilska R, Rumbaugh KP, Wu J, Liu Q, Li W (2020) Adhesive, self-healing, and antibacterial chitosan hydrogels with tunable two-layer structures. ACS Sustain Chem Eng

Workman S, Richter MM. The effects of nonionic surfactants on the tris (2, 2'-bipyridyl) ruthenium (II) - tripropylamine electrochemiluminescence system. Anal Chem. 2000;72(22):5556-61.

Yazdanparast S, Benvidi A, Banaei M, Nikukar H, Tezerjani MD, Azimzadeh M. Dual-aptamer based electrochemical sandwich biosensor for MCF-7 human breast cancer cells using silver nanoparticle labels and a poly (glutamic acid)/ MWNT nanocomposite. Microchim Acta. 2018;185(9):405.

Zamani-Ahmadmahmudi M, Nassiri SM, Rahbarghazi R. Serological proteome analysis of dogs with breast cancer unveils common serum biomarkers with human counterparts. Electrophoresis. 2014;35(6):901-10.

Zanut A, Fiorani A, Canola S, Saito T, Ziebart N, Rapino S, Rebeccani S, Barbon A, Irie T, Josel H-P. Insights into the mechanism of coreactant electrochemiluminescence facilitating enhanced bioanalytical performance. Nat Commun. 2020;11(1):1-9.

Zhang M, Gao G, Ding Y, Deng C, Xiang J, Wu H. A fluorescent aptasensor for the femtomolar detection of epidermal growth factor receptor-2 based on the proximity of G-rich sequences to Ag nanoclusters. Talanta. 2019;199:238-43.

Zheng Y, Wang A, Lin H, Fu L, Cai W. A sensitive electrochemical sensor for direct phoxim detection based on an electrodeposited reduced graphene oxide-gold nanocomposite. RSC Adv. 2015;5(20):15425-30.

Zhu Y, Chandra P, Shim Y-B. Ultrasensitive and selective electrochemical diagnosis of breast cancer based on a hydrazineAu nanoparticle-aptamer bioconjugate. Anal Chem. 2012;85(2):1058-64.

\section{Publisher's Note}

Springer Nature remains neutral with regard to jurisdictional claims in published maps and institutional affiliations. 